\title{
Development Potential of Retail Chain of Consumer Cooperation Based on the Reverse Franchising Technology
}

Tarasova E. E.

Department of Hotel and Tourist Service, Commerce and Advertising

Belgorod University of Cooperation, Economics and Law Belgorod, Russia

Rozdolskaya I.V.

Marketing and Management Department Belgorod University of Cooperation, Economics and Law Belgorod, Russia
Makrinova E.I.

Department of Hotel and Tourist Service, Commerce and Advertising

Belgorod University of Cooperation, Economics and Law Belgorod, Russia

Matuzenko E.V.

Department of Hotel and Tourist Service, Commerce and Advertising

Belgorod University of Cooperation, Economics and Law Belgorod, Russia

Glazunova O. A.

Department of Hotel and Tourist Service, Commerce and Advertising Belgorod University of Cooperation, Economics and Law

Belgorod, Russia

\begin{abstract}
In accordance with the "Road map for the Consumer Cooperation System Development for 2017-2021," the main task of its effective functioning is creation of comfortable conditions for the retail trade improvement. The solution to the problem is in the implementation of effective forms of interaction with federal retail chains that contribute to survival and sustainable development; one of such forms is the reverse franchising technology.

By compiling completed earlier theoretical developments, including the authors' ones, and basing on extensive practical experience, in particular domestic, the article systematizes the types of franchising according to various criteria and specifies the benefits obtained from using each of them; confirms effectiveness of the retail chains functioning while using reverse franchising technology; proves the necessity and the possibility (by establishing the conformity of the stores' material and technical resources with the franchisor's requirements) of successful application of this technology by organizations of consumer cooperation.

Particular attention is paid to the study of performance results of the retail chain COOP-Pyaterochka, established under an agreement with the X5 Retail Group, which allowed the authors to specify the benefits of using reverse franchising by
\end{abstract}

organizations of consumer cooperation, which include improving store design and assortment, increasing customer loyalty, reducing costs, rising qualification level of the staff, improving efficiency of logistics.

The study resulted in justification of a methodological approach to assessing the effectiveness of using reverse franchising technology by organizations of consumer cooperation based on the use of an indicator system of the investment project effectiveness.

Keywords: consumer cooperation, reverse franchising, retail, retail chains, franchisee, franchisor

\section{INTRODUCTION}

Many scientific works have been devoted to the problems of expansion and performance of consumer cooperation retail trade at various stages of its development; particularly noteworthy are the works of V.I. Teplov, L.P. Nagovitsina, E.V. Isaenko, T. N. Prizhigalinskaya, D.S. Ternovsky and others [4, 7-9, 12 and others]. 
Actual issues and experience of development of franchising as an effective retail trade business technology were considered by domestic and foreign scientists [1-2, 6, etc.]. However, development problems of consumer cooperative organizations' retail trade based on reverse franchising technology are poorly represented in modern scientific literature.

This research is a continuation of the authors' previous studies [5, 9-12, 14, etc.] on the problems and prospects of retail trade and functioning of consumer cooperative organizations, and is devoted to the analysis of theoretical developments and practical experience in using the reverse franchising technology, selecting the best practices and giving recommendations on their practical application.

\section{Methods AND MATERIALS}

Works of domestic and foreign scientists in the field of franchising development in retail chains became the theoretical and methodological basis of the study. The validity and reliability of the research results are grounded on looking into economic events genesis, analyzing causality between economic phenomena, as well as using of general scientific methods (dialectics, synthesis, systemacity, complexity), etc.

\section{RESULTS}

Increased competition in retail trade determines the demand for new forms of collaboration between enterprises, including competitors' establishments; one of such forms is franchising. The use of new forms of interaction between enterprises and retailers will contribute to their survival in a competitive environment, as well as sustainable development in the long run.

Traditionally, franchising is seen as a way of organizing business relations between independent companies and / or individuals, when one of the parties (franchisee) receives an official permission from the other one (franchisor) to use the service mark, corporate identity, business reputation, knowhow and a ready-made business model for a certain fee (royalty) [18].

A survey of various types of franchising, which are used in Russia in many fields of activity, allowed the authors to systematize them according to the selected classification criteria and specify a franchisee's benefits through the use of each type (Table I).
TABLE I. SYSTEMATIZATION OF THE FRANCHISEE'S BENEFITS FROM THE USE OF VARIOUS TYPES OF FRANCHISING (DEVELOPED BY THE AUTHORS)

\begin{tabular}{|c|c|c|}
\hline $\begin{array}{l}\text { Criterion of } \\
\text { franchising } \\
\text { classification } \\
\end{array}$ & $\begin{array}{c}\text { Type of } \\
\text { franchising }\end{array}$ & Franchisee's enefits \\
\hline \multirow[t]{4}{*}{$\begin{array}{l}\text { Kind of } \\
\text { activity }\end{array}$} & Tradeable & $\begin{array}{l}\text { The franchisee receives the right to sell } \\
\text { goods produced under the franchisor's } \\
\text { brand name }\end{array}$ \\
\hline & Productive & $\begin{array}{l}\text { The franchisee will both own the } \\
\text { patented technology for goods } \\
\text { production and be able to use it in future }\end{array}$ \\
\hline & Service & $\begin{array}{l}\text { The franchisee is given the right to use } \\
\text { the franchisor's know-how to provide } \\
\text { certain types of services; he/she is } \\
\text { provided with equipment, advertising } \\
\text { and marketing technology, access to } \\
\text { certain information and databases }\end{array}$ \\
\hline & Hybridous & $\begin{array}{l}\text { The franchisee obtains the right to sale } \\
\text { goods produced by the franchisor } \\
\text { through his/her outlets and provides } \\
\text { services related to the use of these } \\
\text { products }\end{array}$ \\
\hline \multirow[t]{4}{*}{ Chain } & Straight & $\begin{array}{l}\text { The franchisee is supported by the } \\
\text { franchisor in the following aspects: } \\
\text { consultations, staff training, marketing } \\
\text { and advertising technology for business } \\
\text { promotion }\end{array}$ \\
\hline & $\begin{array}{l}\text { Franchising } \\
\text { - territory } \\
\text { development }\end{array}$ & $\begin{array}{l}\text { The franchisee receives the right to } \\
\text { open a certain number of franchising } \\
\text { outlets in the designated area and within } \\
\text { the established deadlines }\end{array}$ \\
\hline & $\begin{array}{c}\text { Master - } \\
\text { franchising }\end{array}$ & $\begin{array}{l}\text { The franchisee receives a wide range of } \\
\text { the franchisor's rights and obligations } \\
\text { and has the right to independently create } \\
\text { enterprises and sell franchises in the } \\
\text { designated area }\end{array}$ \\
\hline & Reverse & $\begin{array}{l}\text { The franchisee is exempted from paying } \\
\text { a lump-sum contribution; business } \\
\text { organization costs are reduced }\end{array}$ \\
\hline \multirow[t]{2}{*}{$\begin{array}{c}\text { Franchisor's } \\
\text { know-how }\end{array}$} & $\begin{array}{c}\text { Product } \\
\text { distribution } \\
\text { franchising }\end{array}$ & $\begin{array}{l}\text { The franchisee has the right not only to } \\
\text { sell the given assortment of goods or to } \\
\text { provide certain services under the } \\
\text { franchisor's trademark, but also to } \\
\text { increase the trading area }\end{array}$ \\
\hline & $\begin{array}{l}\text { Business } \\
\text { format } \\
\text { franchising }\end{array}$ & $\begin{array}{l}\text { The franchisee receives from the } \\
\text { franchisor the right to use the trademark } \\
\text { and business technology; he/she also } \\
\text { receives competitive advantages and } \\
\text { becomes part of the overall corporate } \\
\text { system }\end{array}$ \\
\hline
\end{tabular}

Among the listed types of franchising there is a relatively new type used in retail chains. It is reverse franchising, which represents a particular business scheme when a franchisor conveys the right to conduct business under the franchisee's trademark, but it is designed so that payments for the activities are paid not to the copyright holder but to the user, that is, the franchisee [18].

According to the authors, the main difference between reverse franchising and the direct type of retail business lies in the fact that the owner almost completely controls the work of shops opened under the contract. At the same time, the franchisor not only invests in a retail outlet, but also minimizes its risks, reducing the brand buyer's functions. The outlet owner neither forms the assortment nor bears costs for commodity resources formation, since the franchisor hands 
over the goods to him/her (for alcohol, under the current legislation, they draw up a supply agreement).

It should be noted that for the first time this model was used by X5 Retail Group in shops of its own formats: Perekrestok, Pyaterochka, Perekrestok-express and CityMag. They offered reverse franchise both to those partners who have already worked against direct franchising and to new ventures.

An agency agreement was added to the main contract under which the partner is provided with goods for sale for a monetary reward. Thus, X5 Retail Group fully assumes the assortment formation, product delivery and pricing policy, and the franchisee shop becomes a complete analogue of the X5 Retail Group's outlet. Whereas the franchise owner takes control over the main operations, the "reverse" franchisee bears obligations in the amount of $75-77 \%$ from the sale proceeds, the remaining $23-25 \%$ he/she receives in the form of agency fees, which is spent on staff salaries, rent, utilities services and royalties.

Currently, ten retail chains are successfully operating on the Russian market using reverse franchising technology. Akkond is one of the leaders in amount of franchised shops, having opened over 150 enterprises in past 5 years. Based on the both sales revenue analysis and financial results, it can be concluded that the use of reverse franchising technology allows the retail chain Akkond to function effectively in a highly competitive market (Fig. 1).

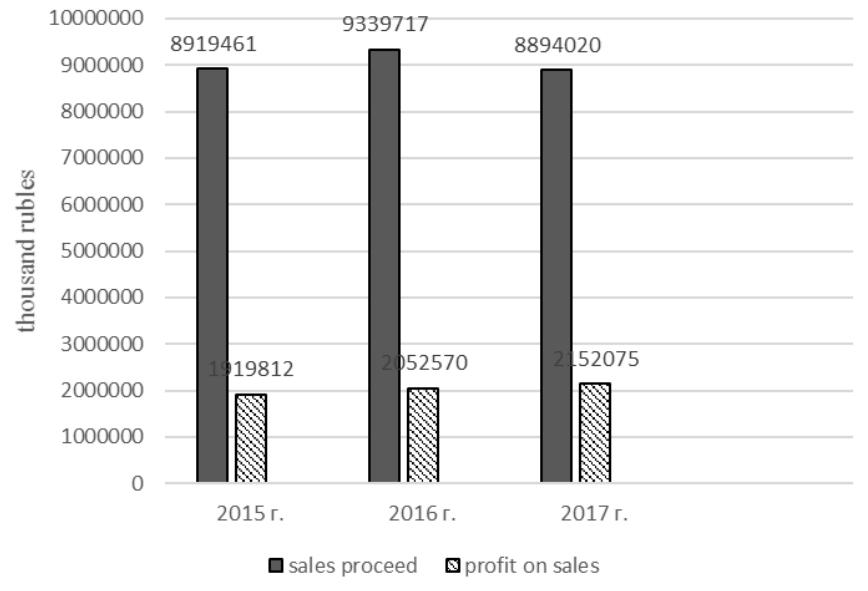

Fig. 1. Economic indicators of the retail distribution chain Akkond's activity for 2015-2017, thousand rubles. Compiled from [17]

Consumer cooperation, as an economic entity operating mainly in rural areas, has an extensive retail chain. However recently, there has been a trend towards decreasing the number of shops in the system of consumer cooperation: in 2017 there were 20,934 units, down 3839 compared to 2016. The decrease in the number of consumer cooperation shops led to a decrease in retail turnover and profit (Fig. 2).

In 2018, the retail trade turnover of organizations of consumer cooperation amounted to 127727 thousand rubles, down 25717 thousand rubles compared to 2016. The Figure 1 data lead us to the conclusion that over the past 3 years organizations of consumer cooperation have been unprofitable.

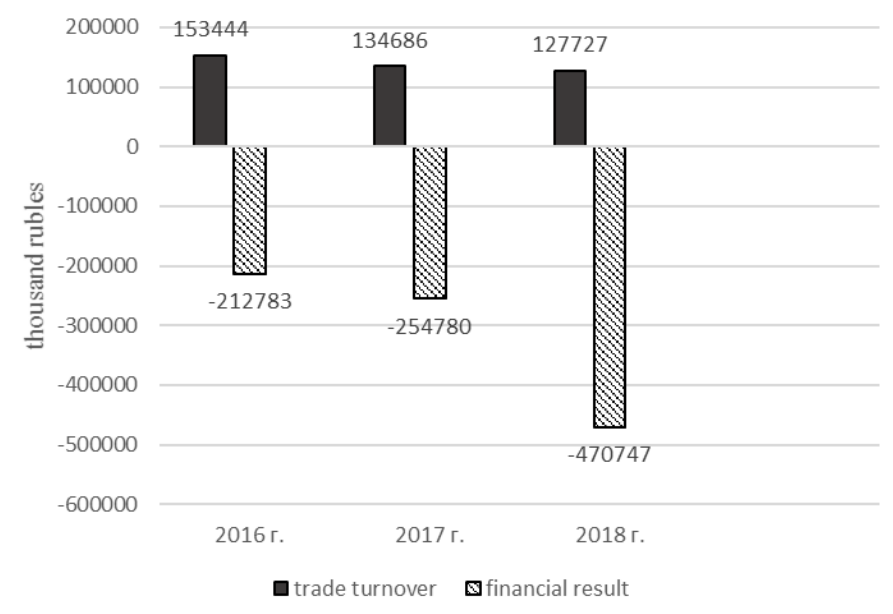

Fig. 2. Economic indicators of consumer cooperation organizations' activity for 2016-2018, thousand rubles

Thus, at present, in retail trade of consumer cooperation there is a trend towards turnover decrease and financial results decline, which makes it uncompetitive compared to federal retail chains that have substantial financial resources, high retail turnover and well-functioning logistics. Based on the presented experience, it can be concluded that in order to increase consumer cooperatives' retail trade efficiency it is advisable to seek cooperation with federal retail chains. According to the authors, this will make it possible to determine the conditions under which federal retail chains are ready to interact with consumer cooperatives, and consumer cooperative shops can benefit from getting additional assortment and using the retailers' logistics network. Of particular interest in that connection is development and implementation of the collaboration agreement (in the Moscow Union of Consumer Societies) with the retail chain Pyaterochka [13].

Under this agreement, consumer cooperation shops, on the basis of which the retail chain COOP-Pyaterochka was created, remain in the ownership or operational management of cooperative organizations. Pyaterochka provides them with technologies, purchasing capabilities and standards. The process occurs on a voluntary basis and is mutually beneficial.

This collaboration agreement formats are stores united under the joint brand of COOP-Pyaterochka. Since cooperative stores cannot provide consumers only with their own products considering that customers, most commonly, need related goods, Pyaterochka supplements the assortment with high-demand goods at the lowest possible prices, which helps cooperative shops eliminate middlemen and reduce prices under the agreement.

Among the main advantages of the project is the ability to use the logistics system of the federal chain X5 Retail Group, which can also serve as a means for bringing cooperative goods from different regions. The reverse franchise agreement between X5 Retail Group and the system of consumer cooperation should be valid for five years. By the year 2021, 
the parties agreed to open in the retail chain Pyaterochka up to 5 thousand departments in a "shop-in-shop" format, where they are ready to sell farm products and goods of organizations of consumer cooperation.

The study showed that currently in the system of consumer cooperation in Russia there are about 20 thousand functioning stores, as well as another 11 thousand facilities, hosting stores of COOP-Pyaterochka, can be opened. In addition, for exercising reverse franchising in the consumer cooperation system, it is planned to open a thousand stores under the COOP-Pyaterochka brand within three years. Their proceeds will be stated in X5 Retail Group's accounts. X5 Retail Group will reconstruct consumer cooperation shops and introduce "modern trade standards". COOP-Pyaterochka will use the logistics network and the supplier base of X5 Retail Group. This will push commodity prices downwards and increase retail turnover and profits due to development of retail chain in regions. It must be emphasized that the agreement makes it possible to supply goods from the assortment of Pyaterochka's chain of stores to outlets of consumer cooperation, which are not included into the partnership program.

Having studied the X5 Retail Group's basic requirements imposed to franchising facilities (Fig. 3), we came to the conclusion that most shops of consumer cooperation satisfy the requirements for sales area, availability of necessary electrical power, shops location, staff profile, investment volume and others.

As part of the signed collaboration agreement between the Federal Trade Network Pyaterochka and the Moscow Regional Consumer Cooperation Union, the first shop RaipoPyaterochka was opened in July 2015. The use of reverse franchising technology contributed to a 6-fold increase in the turnover of this trading company.

\begin{tabular}{|c|}
\hline Basic requirements for franchisees \\
\hline Sales areas - from $250 \mathrm{~m}^{2}$. \\
\hline The actual availability of the necessary electrical power \\
\hline $\begin{array}{l}\text { Shops location-close to residential buildings and in the areas of } \\
\text { active construction work }\end{array}$ \\
\hline Franchisee's operating costs $-10-10,5 \%$ \\
\hline Staff number - 10-12 employees (depending on the size of the shop). \\
\hline $\begin{array}{l}\text { The territory of presence - all the economic regions of Russia where } \\
\text { the retail chain Pyaterochka operates }\end{array}$ \\
\hline $\begin{array}{l}\text { Partner's investment amount - from } 8 \text { million rubles up to } 22 \text { million } \\
\text { rubles }\end{array}$ \\
\hline $\begin{array}{l}\text { The payback period - two years, the average income }-500,000 \text { rubles } \\
\text { per month }\end{array}$ \\
\hline
\end{tabular}

Fig. 3. Basic requirements for franchisees operating under the trademark Pyaterochka
The sales area of the shop Raipo Pyaterochka is 285 sq. $\mathrm{m}$. It serves more than 3 thousand residents of the surrounding villages and dacha condominiums. The staff of RaipoPyaterochka consists entirely of Raipo employees educated at the Pyaterochka training center and chain shops. The retail chain Pyaterochka provides all business processes, an IT system, goods, logistics, etc., and the Moscow Regional Consumer Cooperation Union (MRCCU) exersises operational management of retail facilities.

At present, the federal retail chain Pyaterochka has 800 supermarkets in the Moscow Region, and Moscow Regional Consumer Cooperation Union has more than 600 shops. Within the framework of a joint project and in accordance with the signed Agreement, the retail chain Pyaterochka plans to open under a joint brand more than 150 stores in the Moscow region within a three-year-period.

The study made it possible to identify and systematize a number of reverse franchising benefits in the retail trade chain of consumer cooperation (Fig. 4).

Manufacturers and retailers see franchising as a way to create a stable and flexible network of retail outlets. Establishment and maintenance of the stable franchise chains' operation and management is a complex task that requires significant costs. It makes it necessary to develop modern methods for assessing effectiveness of franchise chains.

We support the opinion of the authors [3], who believe that franchise enterprises should be considered as investment projects. Based on the study of economic literature for assessing operational effect of the consumer cooperation retail network using the reverse franchising technology, the authors worked out a methodological approach based on the use of a system of performance indicators for evaluating the investment project (Table II).

TABLE II. THE SYSTEM OF INDICATORS FOR ASSESSING OPERATIONAL EFFECT OF THE CONSUMER COOPERATION RETAIL NETWORK USING REVERSE FRANCHISING TECHNOLOGY

\begin{tabular}{|c|c|c|}
\hline $\begin{array}{c}\text { Indicator } \\
\text { name }\end{array}$ & Formula for calculating & Indicator value \\
\hline $\begin{array}{l}\text { Present } \\
\text { discounted } \\
\text { value }\end{array}$ & ТДС $=P_{T}\left(3_{T}\right) /(1+T)^{T}$ & $\begin{array}{l}\text { The result shows the } \\
\text { amount of franchisor's } \\
\text { financial investments to } \\
\text { obtain a certain amount } \\
\text { of profit }\end{array}$ \\
\hline $\begin{array}{l}\text { Net present } \\
\text { value }\end{array}$ & $N P V=\sum_{t=0}^{T}\left(P_{T}-3_{T}\right) \times K Д$ & $\begin{array}{l}\text { If the result is positive, } \\
\text { investing is advisable }\end{array}$ \\
\hline $\begin{array}{l}\text { Profitability } \\
\text { index }\end{array}$ & $D P I=\frac{\sum_{t=0} \overline{(1+r)^{t}}}{\sum_{t=0}^{n} \frac{I_{t}}{(1+r)^{t}}}$ & $\begin{array}{l}\mathrm{DPI}=1 \text {, then the project } \\
\text { is considered effective }\end{array}$ \\
\hline $\begin{array}{l}\text { Internal } \\
\text { payback } \\
\text { ratio }\end{array}$ & $\begin{array}{l}\text { IRR }=\mathrm{ra}+(\mathrm{rb}-\mathrm{ra}) * \mathrm{NPVa} / \\
/(\mathrm{NPV}-\mathrm{NPVb})\end{array}$ & $\begin{array}{l}\text { If the value of the } \\
\text { indicator is higher than or } \\
\text { equal to the cost of } \\
\text { capital, then the operation } \\
\text { of the franchise chain is } \\
\text { effective }\end{array}$ \\
\hline
\end{tabular}




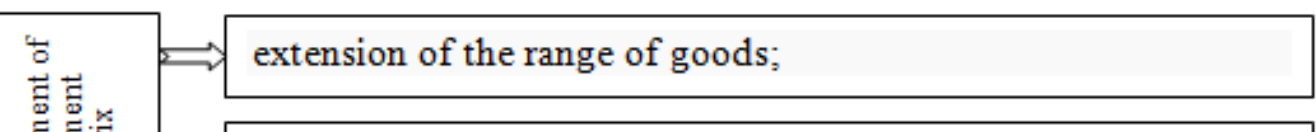

establishing sales offices for marketing farm products and for products of organizations of consumer cooperation;

\begin{tabular}{|l|l|l|} 
extablishing sales offices for marketing farm products and for \\
products of organizations of consumer cooperation;
\end{tabular}

Fig. 4. Systematization of reverse franchising benefits for retail enterprises of consumer cooperation (developed by the authors)

Due to the authors' opinion, calculation of these indicators for assessing operational effect of the franchise chain makes it possible to predict the results of consumer cooperation retail enterprises' activity using reverse franchising.

\section{CONCLUSION}

Thus, in the retail trade of consumer cooperation, it is necessary to use new approaches to management; strengthen image of the organization; increase the financial stability and technological effectiveness of retail enterprises. This can be facilitated by joint efforts of consumer cooperation and wellknown federal chains, such as X5 Retail Group, through the use of reverse franchising technology.

The reverse franchising used by X5 Retail Group is financially beneficial for organizations of consumer cooperation from the financial side, and from the retailer's 
[8] Tarasova E.E., Kadatskaya D.V. (2015) Theoretical Aspects and Methodological Approaches to Sales Services Quality Assessment. J Internet Bank Commer S1: 008. doi:10.4172/1204-5357.S1-008

of view, control over business processes simplifies administration and provides a synergistic effect for logistics, procurement and organic growth.

\section{REFERENCES}

[1] Campbell, D. Business strategy: an introduction [Text] / D. Campbell, D. Edgar \& G. Stonehouse. Palgrave Macmillan, 2011. - 363 p.

[2] Freeland, John G. The ultimate CRM handbook: strategies and concepts for building enduring customer loyalty and profitability [Text] / John G. Freeland. - McGraw-Hill, 2003. - 353 p.

[3] Innovation and development [Text] / Edited by K.J. Joseph. Routledge, 2017. - V.7. - №2. - 307 p.

[4] Isaenko EV, Degtyar ON (2015) Self-service in Retail Trade of ConsumerCooperation: Assessment and Strategy of Development. J Internet Bank Commer S1: 009. doi:10.4172/1204-5357.S1-009

[5] Kraenrle C.A. Members and cooperative of cooperatives// American Cooperation, 1989. p. 45-47.

[6] Prizhigalinskaya T.N., Ternovsky D.S., Ukolova L.V., Piankova M.G. Strategic Potential And Potential Of Consumer Cooperation Organization's Development: Methodology Of Formation And Assessment // Journal of Internet Banking and Commerce. 2015. T. 20. № S1. C. 006.

[7] Suder, G. Doing Business in Europe [Text] / G. Suder. - SAGE Publications, 2011. -452 p.

[9] Teplov V.I., Tarasova E.E., Matuzenko E.V., Alyabieva M.V., Belenov O.N. Commercial activity business processes reengineering: theoretical, methodological and practical aspects//Journal of Advanced Research in Law and Economics. 2016. T. 7. № 3. C. 649-661.

[10] Makrinova E.I., Avilova Zh.N., Shilenko S.I., Shilenko S.M. Features of modeling a competitive development strategy for a Russian importing company // Fundamental Research. 2019.No 3.P. 46-50.

[11] Matuzenko E.V., Glazunova O.A. Franchising: problems of functioning and directions of business creation // Herald of the Belgorod University of Cooperation, Economics and Law. 2018.No 5 (72).P. 224-233.

[12] Nagovitsina L.P., Drozdova M.I., Nagovitsin A.A. Consumer cooperation opportunities in the conditions of territorial retail expansion. // Herald of the Belgorod University of Cooperation, Economics and Law. 2019.No 3 (76). P. 261-273.

[13] Potential of the joint project of X5 and the Centrosoyuz is being estimated at 1,000 stores during 3 years [Electronic resource]. - Access mode: https://www.vedomosti.ru/press_releases/2017/04/12 Contact 11.09.2019.

[14] Rozdolskaya I.V., Makrinova E.I., Naydenov V.N. Theory and practice of developing a market-oriented mechanism of managerial activity in organizations of consumer cooperation. - monograph. - Belgorod University of Cooperation, Economics and Law. Belgorod, 2006.

[15] http://b2bcontact.ru

[16] https://newbusiness.su/obratnyj-franchajzing.html

[17] https://www.audit-it.ru/buh_otchet/2126000147_ao-akkond

[18] https://rusfranch.ru. 